\title{
A NEW SPECIES OF FICUS (MORACEAE) FROM COSTA RICA
}

\author{
C. C. BERG
}

Instituut voor Systematische Plantkunde, Heidelberglaan 2, 3584 CS Utrecht

Ficus cahuitensis C.C.Berg spec. nov.

Arbor terrestris. Ramuli foliosi circa $1 \mathrm{~cm}$ diam., subglabri. Lamina oblanceolata vel subobovata, $10-28 \mathrm{~cm}$ longa, $3,5-9 \mathrm{~cm}$ lata, brevissime acuminate, basi (sub)acuta, faciebus subglabris; vennae laterales $10-16$ pro latere; petiolus $1-1,5(-2,5) \mathrm{cm}$ longus; stipulae 1,5-4 cm longae, (sub)persistentes, subglabrae. Syconia axillaria bina, (sub)glabra, circa $2 \mathrm{~cm}$ diam.

Tree ( $5 \mathrm{~m}$ tall; terrestrial); latex white. Leafy twigs c. $1 \mathrm{~cm}$ thick, glabrous or with sparce, minute, brown, pluricellular hairs; periderm peeling off.

Leaves (at least on flowering branches) aggregate: lamina oblanceolate to subobovate, $10-28 \mathrm{~cm}$ long, $3.5-9 \mathrm{~cm}$ wide, coriaceous, base (sub)acute, apex very shortly acuminate; upper surface glabrous, lower surface with minute, brown, appressed, pluricellular hairs on the main feins (glabrescent); lateral veins 10-16 pairs (especially the lower ones often not distinctly loop-connected), without parallel tertiary veins; petiole $1-1.5(-2.5) \mathrm{cm}$ long, $2-3.5 \mathrm{~mm}$ thick, glabrous, stipules $1.5-4 \mathrm{~cm}$ long, (sub)persistent, margin ciliolate, outside glabrous, inside glabrous or puberulous at the base.

Figs in pairs in the leaf axils, sessile; basal bracts 2 , c. $5 \mathrm{~mm}$ long, minutely puberulous; receptacle (depressed) globose, c. $2 \mathrm{~cm}$ (when dry c. $1.5-1.8 \mathrm{~cm}$ ) in diameter, minutely puberulous, dark green with pale green or purplish spots, ostiole c. $4 \mathrm{~mm}$ in diameter, plane.

Seed flowers sessile, tepals 3, almost free, 1-2.5 mm long (sub)acute, style $1.5-2 \mathrm{~mm}$ long; gall flowers up to $3 \mathrm{~mm}$ long pedicellate, tepals 3 , almost free, 1-1,5 mm long, rounded, style c. $1 \mathrm{~mm}$ long; stigmas 2 or 1 ; fruits ovoid to subglobose to ellipsoid, 1.3-3 mm long, yellow; "gall fruits" ovoid to subglobose, $1-1.5 \mathrm{~mm}$ long, brown; interfloral bracts $1-1.5 \mathrm{~mm}$ long; staminate flowers not seen.

TYPUS: Berg 942, Costa Rica, Limon, Pta.Cahuita, near shore (holo-,U; iso-, F).

Additional collection: Burger \& Ramirez 3978, Costa Rica, Cartago, between Turrialba and Moravia, along río Tuis (CR, F).

The new species is reminiscent of $F$. costaricana (Liebm.) Miq. because of the persistent stipules and sessile figs, but appears to be more closely related to $F$. obtusifolia H.B.K.

The species can be keyed out in the key to the species of Ficus in Flora costaricensis (Fieldiana Bot. 40: 141, 1977) as follows: 1 -2 - 10-11-18-19 26a. Stipules (usually) persisting . . . . . . . . . 26' 26b. Stipules (usually) caducous . . . . . . . . . . . 27 


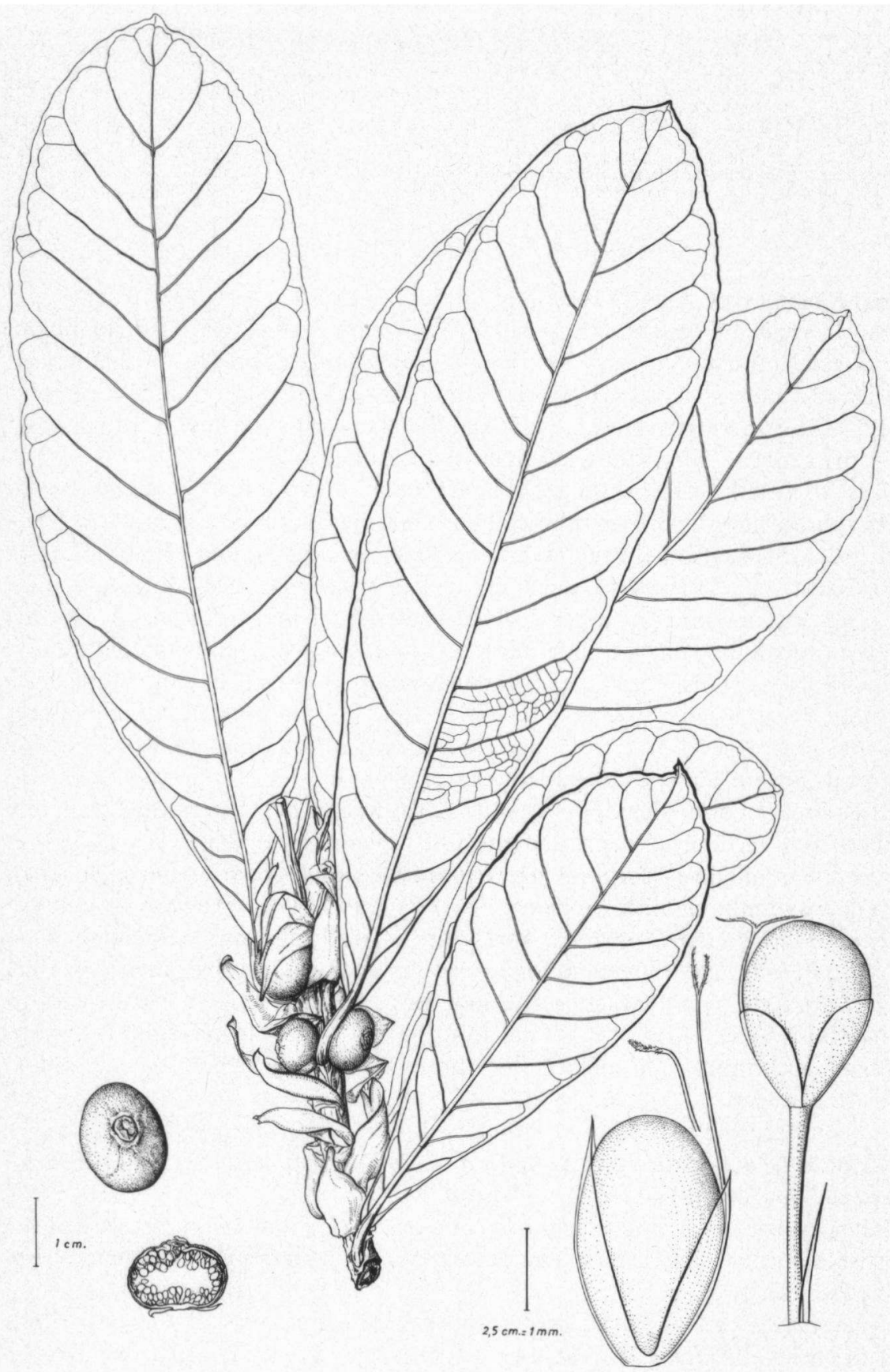

Fig. 1. Ficus cahuitensis. Leafy twig with figs, pedicellate gall flower, and sessile seed flower (from Berg 942). 
26'a. Lateral veins $3-8(-10)$ pairs; stipules with white hairs along the midrib . . . . . . . . . . . . . . F. costaricana. $26^{\prime} \mathrm{b}$. Lateral veins $10-16$ pairs; stipules glabrous along the midrib F. cahuitensis.

\section{ACKNOWLEDGEMENTS}

The author is much indebted to Dr. K. U. Kramer (Zürich) for correcting the English text and contributing the latin diagnosis. Miss E. M. Hupkes van der Elst prepared the drawing. 